\title{
Analisis Pola Konsumsi Pangan Pokok Rumah Tangga di Indonesia Tahun 2000-2014
}

\author{
Indrawan Firdauzi ${ }^{\mathrm{a}, *}$ \\ ${ }^{a}$ Universitas Gadjah Mada
}

\begin{abstract}
Due to the significant contribution to the Gross Domestic Product, the food sector is closely related to the welfare, poverty and standard of living of the Indonesians. As such, changes in food sector's consumption patterns may reflect the changes in the Indonesian economy and welfare of the society. This study aims to analyze the food consumption patterns in Indonesia using pooled cross section data between 2000 and 2014 using the Quadratic Almost Ideal Demand System (QUAIDS). The analysis shows that the consumption pattern in Indonesia was still dominated by rice consumption. Changes in income and commodity prices are more drastic for the poor households; as when there is an increase in income, the percentage of consumption will increase considerably, and when there is an increase in commodity prices, the consumption is substantially reduced.
\end{abstract}

Keywords: food demand; QUAIDS; consumption patterns

\begin{abstract}
Abstrak
Pangan merupakan masalah serius yang dihadapi Indonesia setiap tahunnya. Selain kontribusinya yang besar terhadap Produk Domesti Bruto, pangan juga berkaitan dengan kesejahteraan, kemiskinan dan standar hidup bagi masyarakat Indonesia sehingga perubahan pola konsumsi masyarakat dapat mengubah perekonomian Indonesia dan kesejahteraan masyarakatnya. Penelitian ini bertujuan untuk menganalisis pola konsumsi pangan di Indonesia menggunakan data pooled cross section dengan rentang waktu antara tahun 2000 hingga 2014. Metode yang digunakan adalah Quadratic Almost Ideal Demand System (QUAIDS). Hasil analisis menunjukkan bahwa pola konsumsi di Indonesia masih didominasi oleh beras. Perubahan pendapatan maupun perubahan harga komoditas lebih responsif pada rumah tangga miskin dimana ketika terjadi kenaikan pendapatan persentase konsumsi mereka akan meningkat, dan ketika terjadi kenaikan harga komoditas akan menurunkan konsumsi mereka secara besar-besaran.
\end{abstract}

Kata Kunci: permintaan pangan; QUAIDS; pola konsumsi Kode Klasifikasi JEL: D11; D12; R2

*Alamat Korespondensi Penulis: Fakultas Ekonomika dan Bisnis UGM, Jalan Sosio Humaniora No. 1, Bulaksumur, Caturtunggal, Depok Sub-District, Sleman Regency, Special Region of Yogyakarta 55281. E-mail: indrawanfirdauzi@yahoo.co.id. 


\section{Pendahuluan}

Sandang, pangan, dan papan merupakan kebutuhan yang perlu dipenuhi oleh seseorang agar mampu mendapatkan kesejahteraan pada tingkat paling minimum (Denton, 1990). Dari tiga komoditas yang disebutkan pada konsep tersebut, pangan merupakan salah satu komoditas yang sering menjadi permasalahan di Indonesia. Hal itu dikarenakan masalah pangan di Indonesia hampir muncul pada setiap aspek, baik dari sisi produksi, distribusi, dan konsumsi (Pangaribowo \& Tsegai, 2011). Pada sisi produksi, terjadinya kegagalan panen akibat musim yang tidak mendukung bagi sektor pertanian dan terbatasnya faktor produksi yang ada. Pada sisi distribusi, muncul permasalahan dimana sulitnya akses yang ditempuh hingga ke tangan konsumen. Pada sisi konsumsi, perbedaan kemampuan ekonomi dan selera masyarakat mempengaruhi bagaimana suatu komoditas dapat diakses oleh individu.

Di Indonesia, ketahanan pangan selalu menjadi bahasan serius dalam setiap pemilihan umum presiden dan wakil presiden. Alasan mendasar dikarenakan besarnya proporsi PDB terhadap pengeluaran rumah tangga khususnya belanja makanan (Badan Pusat Statistik, 2019). Selain itu, adanya keterkaitan antara ketahanan pangan dengan kemiskinan, kesejahateraan, dan standar hidup yang layak bagi masyakarat di Indonesia menyebabkan permasalahan pemenuhan kebutuhan pangan menjadi sangat krusial bagi perekonomian dan keberlangsungan hidup masyarakat di Indonesia. Oleh sebab itu, pemerintah mengatur ketahanan pangan dalam berbagai bentuk peraturan dan undang-undang sebagai komitmen untuk menjaga ketahanan pangan. Dalam UU No. 8 Tahun 2012 tentang pangan, menegaskan bahwa pangan merupakan kebutuhan dasar manusia yang paling utama dan pemenuhannya merupakan bagian hak asasi manusia yang dijamin pada UUD 1945. Dengan demikian, negara berkewajiban mewujudkan ketersediaan dan pemenuhan konsumsi pangan yang cukup, aman, bergizi, dan seimbang pada tingkat nasional maupun daerah di seluruh Indonesia.

Meskipun pemerintah telah berusaha untuk menjaga ketersediaan dan pemenuhan konsumsi masyarakat terhadap kebutuhan pangan, permasalahan kebutuhan pangan masih terus berlanjut. Salah satu faktor yang memengaruhi adalah bertambahnya jumlah penduduk yang tidak bisa dihindari sehingga menciptakan persaingan yang lebih rumit dalam mengakses bahan pangan dan menyebabkan permasalahan terhadap pemenuhan asupan yang layak bagi masyarakat. Selama ini pemerintah selalu berupaya untuk mewujudkan ketahanan pangan hanya melalui kebijakan yang berfokus pada daerah. Namun, dalam aplikasinya ketahanan pangan di tingkat daerah belum tentu menjamin terwujudnya ketahanan pangan hingga ke tingkat rumah tangga (Borton \& Shoham, 1991). Sebab, ketersediaan pangan bukanlah satu-satunya faktor penentu ketahanan pangan dapat tercapai hingga ke tingkat rumah tangga. Fakta bahwa perbedaan kemampuan ekonomi memengaruhi rumah tangga dalam mengakses kebutuhan pangan (Braun, 1995). Selain itu, selera masyarakat menjadi pertimbangan tersendiri bagi mereka untuk memilih keinginan mengonsumsi kebutuhan pangan. 
Pola konsumsi masyarakat turut andil dalam pertimbangan mereka untuk melakukan konsumsi, baik dari segi kondisi perekonomian dan berbagai karakteristik masyarakat lainnya. Kemudian, perubahan harga yang sangat fluktuatif juga memengaruhi konsumsi di masyarakat. Oleh karena itu, dalam Renstra Kementrian Perdagangan Republik Indonesia (2014), pemerintah memiliki sasaran agar terkendalinya harga bahan pokok sehingga harga dan kebutuhan tetap terjangkau sesuai kondisi masyarakat. Selain itu, disparitas harga bahan pangan pokok antar provinsi perlu diturunkan sehingga kelangkaan dan penimbunan pangan dapat diminimalisir.

Penting untuk mengetahui pola konsumsi dan respons rumah tangga terhadap perubahan harga pada suatu komoditas tertentu. Hal ini dapat mengarahkan pemerintah untuk melakukan pertimbangan, kontrol, dan menemukan solusi yang tepat ketika terjadi perubahan harga komoditas tertentu sehingga mampu menekan eksternalitas negatif yang mungkin terjadi akibat perubahan tersebut. Dengan kebijakan yang tepat, ketika terjadi perubahan harga, khususnya ketika harga naik, kesejahteraan masyarakat yang hilang dapat ditekan seminimal mungkin. Oleh sebab itu, penelitian ini bertujuan untuk menganalisis pola konsumsi dan respons rumah tangga dalam menghadapi perubahan harga komoditas pangan dan perubahan pendapatan mereka. Penelitian ini berfokus pada pola konsumsi rumah tangga dari waktu ke waktu antar daerah di Indonesia. Kontribusi dari penelitian ini diharapkan mampu memberikan pandangan tentang pola konsumsi di Indonesia dan mampu memberikan pemahaman serta pengetahuan tentang komoditas pangan yang responsif bagi masyarakat di Indonesia.

Lanjutan dari paper ini tersusun dengan sistematika sebagai berikut. Pada bagian kedua membahas tentang studi dari penelitian terdahulu, bagian ketiga menjelaskan metodologi dan data yang digunakan pada penelitian ini, bagian keempat menjelaskan hasil dan pembahasan, dan terakhir adalah kesimpulan dan implikasi kebijakan.

\subsection{Penelitian Terdahulu}

Penelitian mengenai ketahanan pangan dan konsumsi pangan telah banyak dilakukan dengan berbagai metode dan pendekatan. Penelitian tersebut memberikan referensi kepada peneliti terkait analisis terhadap pola konsumsi rumah tangga, khususnya sistem permintaan pangan. Beberapa penelitian menjelaskan bahwa pola konsumsi makanan di negara berkembang umumnya didominasi oleh konsumsi bahan makanan pokok (Alexandri et al., 2015; Le, 2008; Dona et al., 2018; Olubukunmi et al., 2016). Hingga saat ini, Indonesia memiliki pola konsumsi yang sama dengan negara berkembang lainnya, bahkan nilai dari pengeluaran yang digunakan untuk membelanjakan bahan makanan pokok lebih dari $40 \%$ dari pendapatannya (Faharuddin et al., 2019).

Banyak penelitian yang menganalisis tentang pola konsumsi rumah tangga menggunakan model dan metode yang berbeda seperti Dunne \& Edkins (2005) yang menganalisis pola konsumsi rumah tangga menggunakan metode general 
dynamic log-linear equation dan dynamic version of almost ideal demand system, kemudian Mittal (2010) menganalisis pola konsumsi pangan di India menggunakan two stage quadratic almost ideal demand system (2SQUAIDS). Namun, Cranfield et al. (2003) menemukan bahwa model quadratic almost ideal demand system (QUAIDS) mendapatkan hasil parameter yang lebih baik dibanding model permintaan lainnya. Hal tersebut dikarenakan QUAIDS memiliki bentuk fungsi yang lebih fleksibel dan dapat melakukan estimasi lebih baik dalam bentuk permintaan yang teragregasi sehingga mampu menggambarkan kesesuaian dengan hukum Engel.

Penelitian ini sendiri merupakan penelitian ekstensi atau perpanjangan dari penelitian sebelumnya yang dilakukan oleh Pangaribowo \& Tsegai (2011) yang meneliti pola konsumsi pangan rumah tangga termiskin. Meskipun demikian, banyak hal yang membedakan penelitian tersebut dengan penelitian ini, yaitu dari segi jenis komoditas pangan yang dianalisis, variabel demografi yang digunakan untuk estimasi, serta rentang dan tahun data yang berbeda, selain itu penelitian ini berfokus pada komoditas pangan pokok yang menjadi bahan pangan vital menurut Rencana Strategis Kementrian Perdagangan. Selain itu, beberapa variabel demografi yang digunakan dalam penelitian ini diadopsi dari penelitian yang dilakukan oleh Le (2008) di Vietnam, ia menggunakan usia kepala rumah tangga, pendidikan kepala rumah tangga, lokasi rumah tangga, ukuran rumah tangga, dan jenis kelamin kepala rumah tangga.

\section{Metodologi}

\subsection{Data}

Data yang digunakan dalam penelitian ini merupakan data sekunder yang diperoleh dari Indonesian Family Life Survey (IFLS). IFLS mengumpulkan informasi mengenai kondisi sosial ekonomi dan kesehatan rumah tangga yang dilakukan pada beberapa periode, yaitu gelombang 1 pada tahun 1993, gelombang 2 pada tahun 1997, gelombang 3 pada tahun 2000, gelombang 4 pada tahun 2007, dan gelombang 5 pada tahun 2014. Survei IFLS mencakup informasi tentang individu, rumah tangga, dan fasilitas komunitas yang berisi tentang data kondisi sosial ekonomi, kesehatan, pendidikan, dan barang publik yang tersedia di lingkungan rumah tangga. Sampel IFLS berjumlah lebih dari 30.000 individu yang merepresentasikan sekitar 83 persen dari populasi penduduk di Indonesia (Strauss et al., 2016). Penelitian ini secara spesifik menggunakan data pooled cross section dari 3 gelombang, yaitu IFLS 3 di tahun 2000, IFLS 4 di tahun 2007, dan IFLS 5 di tahun 2014. Pemilihan sampel tersebut disebabkan keterbatasan data dimana pada gelombang sebelumnya informasi harga dan konsumsi komoditas belum mencakup pada komoditas interest yang diteliti.

Pemilihan komoditas yang menjadi fokus pada penelitain ini mengacu pada bahan pangan pokok yang dicanangkan oleh Rencana Strategis Kementrian Perdagangan Indonesia 2010-2014, meliputi beras, jagung, minyak goreng, gula, 
daging sapi, daging ayam, telur, susu, terigu, dan kedelai. Beberapa komoditas mengalami keterbatasan data sehingga peneliti melakukan proksi pada beberapa komoditas, seperti gula diproksi menjadi gula pasir dan kedelai diproksi menjadi produk kedelai meliputi tahu dan tempe. Selain variabel dari komoditas pangan, peneliti memasukkan variabel demografi untuk menjaga variansi dan preferensi rumah tangga yang berbeda, adapun variabel tersebut disajikan pada Tabel 1.

Tabel 1: Variabel Penelitian

\begin{tabular}{llll}
\hline \hline Jenis Variabel & Nama Variabel & Skala & Keterangan \\
\hline Dependen & Proporsi pengeluaran komoditas & Rasio & \\
\hline Independen & Harga komoditas & Rasio & \\
& Ukuran rumah tangga & Rasio & \\
& Tahun sekolah kepala rumah tangga & Rasio & \\
& Usia kepala rumah tangga & Rasio & \\
& Tahun Pernikahan & Rasio & \\
& Status pekerjaan kepala rumah tangga & Nominal & 1: bekerja \\
& & & 0: tidak bekerja \\
& Lokasi rumah tangga & Nominal & 1: urban \\
& & & $0:$ rural \\
& Jenis kelamin kepala rumah tangga & Nominal & 1: laki-laki \\
& & $0:$ perempuan \\
\hline
\end{tabular}

Dalam analisis data mikro tidak akan terlepas dari outlier dan missing data. Pada penelitian ini peneliti menggunakan beberapa pendakatan untuk mengatasi masalah tersebut. Missing data dan outlier pada data rumah tangga, peneliti melakukan eliminasi pada data tersebut. Sedangkan untuk missing data pada data harga di fasilitas komunitas, peneliti melakukan pendekatan imputation based yang diperkenalkan oleh Levy \& Lemeshow (2008) dengan memasukkan nilai rerata pada missing data. Missing data pada tingkat desa atau area enumerasi, akan dilakukan imputasi berdasarkan harga rata-rata di tingkat kecamatan. Missing data pada tingkat kecamatan, akan dilakukan imputasi berdasarkan harga ratarata di tingkat kabupaten. Missing data pada tingkat kabupaten, akan dilakukan imputasi berdasarkan harga rata-rata di tingkat provinsi. Missing data pada tingkat provinsi, akan dilakukan imputasi berdasarkan harga rata-rata di tingkat nasional.

Perlakuan terhadap outlier sedikit berbeda dengan missing data. Pada data outlier, peneliti melakukan replacement yang kemudian akan diganti menggunakan data metode imputasi. Tolok ukur dalam penentuan outlier didasarkan pada statistik harga pangan yang di publikasikan oleh Badan Pusat Statistik dengan jenis komoditas dan tahun yang sama dengan pengambilan data. Jika komoditas yang berada pada data IFLS tidak tersedia pada publikasi tersebut, maka peneliti akan melakukan eliminasi berdasarkan dengan spike plot. 


\subsection{Metode Penelitian}

Penelitian ini menggunakan metode Quadratic Almost Ideal Demand System (QUAIDS) yang merupakan pengembangan model Almost Ideal Demand System (AIDS) yang pertama kali diperkenalkan oleh Banks et al. (1997) untuk menganalisis perilaku dan pola konsumsi masyarakat. Sistem permintaan dengan fungsi logaritma kuadratik memungkinkan efek harga yang relatif lebih fleksibel dan selaras dengan kurva Engel serta konsisten dengan teori utilitas serta mampu menunjukkan spesifikasi permintaan pada banyak komoditas. Selain itu, variabel demografi dimasukkan dalam model untuk menjaga variansi, preferensi dan hetergonitas rumah tangga yang berbeda satu sama lain. Adapaun persamaan model QUAIDS yang digunakan dalam penelitian ini adalah sebagai berikut.

$$
\begin{aligned}
w_{i}= & \alpha_{i}+\sum_{j=1}^{k} \gamma_{i j} \ln p_{j}+\left(\beta_{i}+\eta_{i}^{\prime} \boldsymbol{z}\right) \ln \left[\frac{x}{\bar{m}_{0}(\boldsymbol{z}) \alpha(\boldsymbol{p})}\right] \\
& +\left[\frac{\lambda_{i}}{b(\boldsymbol{p}) c(\boldsymbol{p}, \boldsymbol{z})}\right]\left\{\ln \left[\left[\frac{x}{m_{0}(\boldsymbol{z}) \alpha(\boldsymbol{p})}\right]\right]\right\}^{2}+u_{i}
\end{aligned}
$$

dengan:

$\bar{m}_{0}(z): 1+\rho^{\prime} z$ dan $\rho$ adalah vektor paramaeter yang diestimasi $c(p, z)=\prod_{j=1}^{k} p_{j}^{\eta_{j}^{\prime} z}$ kondisi yang membutuhkan asumsi adding-up

ij : komoditas pangan

$w_{i}$ : Proporsi pengeluaran rumah tangga untuk mengkonsumsi komoditas pangan ke-i terhadap total pengeluaran $w_{i}=\frac{p_{i} q_{i}}{x}(x$ merupakan jumlah pengeluaran untuk konsumsi komoditas ke-i) sehingga harus memenuhi syarat $\sum_{i}^{n} w_{i}=1$

$P_{j}$ : harga komoditas ke $j$

$X$ : total pengeluaran rumah tangga untuk konsumsi komoditas.

$z$ : Vektor variabel sosial demografi rumah tangga yang digunakan dalam pene-

litian ini, yaitu:

Z1 : Ukuran rumah tangga

Z2 : Tahun sekolah kepala rumah tangga

$Z 3$ : Status pekerjaan kepala rumah tangga

Z4 : Usia kepala rumah tangga

Z5 : Lokasi rumah tangga

$Z 6$ : Jenis kelamin kepala rumah tangga

Z6 : Tahun pernikahan

$\alpha_{i}, \beta_{i}, \lambda_{i}, \gamma_{i j}:$ parameter

$\eta_{i}, \rho:$ vektor parameter

$u_{i}$ : residual 


\section{Hasil dan Pembahasan}

Penelitian ini terdapat total 13.623 rumah tangga yang terdiri dari 5.298 rumah tangga berasal dari gelombang 3, 5.935 rumah tangga berasal dari gelombang 4, dan 2.390 berasal dari gelombang 5 . Karakteristik rumah tangga yang terpilih menjadi fokus penelitian dirangkum pada Tabel 2 yang menunjukkan bahwa rata-rata jumlah anggota rumah tangga di Indonesia berkisar antara 4 hingga 5 orang dan kepala rumah tangga rata-rata berusia 42 hingga 45 tahun. Pendidikan di Indonesia menunjukkan peningkatan dari tahun ke tahun, dibuktikan dengan tahun pendidikan yang ditempuh kepala keluarga makin membaik. Meskipun demikian, gap tingkat pendidikan masih terjadi antara rumah tangga termiskin dan terkaya, rata-rata rumah tangga termiskin hanya mampu menyelesaikan pendidikan hingga 5 tahun atau setara dengan kelas 5 Sekolah Dasar. Sedangkan rumah tangga terkaya mampu menyelesaikan pendidikannya hingga tingkat 9 tahun atau setara dengan kelas 3 Sekolah Menengah Pertama. Selain itu gap pendidikan juga terjadi pada karakteristik lokasi rumah tangga, rumah tangga yang tinggal di daerah pedesaan rata-rata menempuh pendidikan hingga 5 tahun. Sedangkan rumah tangga di daerah perkotaan mampu menempuh pendidikan hingga 8 tahun atau 2 SMP.

Selain ditemukannya gap antara tahun pendidikan yang ditempuh kepala keluarga juga ditemukan pula gap yang terjadi pada pendapatan dan pengeluaran dari masing-masing karakteristik rumah tangga. Rumah tangga terkaya memiliki pendapatan sebanyak Rp7.114.861/bulan dengan pengeluaran per minggu sebesar Rp261.775. Sedangkan rumah tangga termiskin memiliki pendapatan Rp979.062/bulan dengan pengeluaran perminggu sebesar Rp53.323. Selain itu terlihat pula gap pada karakteristik lokasi, dimana rumah tangga yang tinggal di daerah pedesaan memiliki pendapatan dan lebih rendah dibanding rumah tangga di daerah perdesaan dengan selisih pendapatan sebesar Rp1.255.218. Meskipun pada karakteristik rumah tangga berdasar lokasi memiliki selisih pendapatan yang cukup besar, namun pengeluaran perminggu tidaklah jauh berbeda.

Tabel 3 menunjukkan proporsi masing-masing rumah tangga. Dari hasil analisis yang dilakukan, proporsi kebutuhan pangan pokok di Indonesia masih didominasi oleh beras, selanjutnya diikuti minyak goreng dan gula. Terdapat fenomena yang cukup menarik ditemukan dalam penelitian ini, saat ini jagung tidak lagi menjadi sumber asupan karbohidrat utama, dilihat dari jumlah proporsi yang dikeluarkan oleh rumah tangga hanya berkisar 11\% hingga 13\%. Sumber asupan karbohidrat utama saat ini adalah beras, proporsi yang dikeluarkan rumah tangga berkisar 26\% hingga 38\% dari pengeluaran yang mereka lakukan.

Rumah tangga termiskin mengeluarkan proporsi daging-dagingan yang sangat rendah, baik daging sapi maupun daging ayam. Berbeda dengan rumah tangga terkaya mereka mengeluarkan 13\% dari total pengeluarannya untuk membeli daging ayam, dan $7 \%$ untuk membeli daging sapi. Rumah tangga termiskin cenderung mengalokasikan lebih banyak pengeluaran mereka untuk 


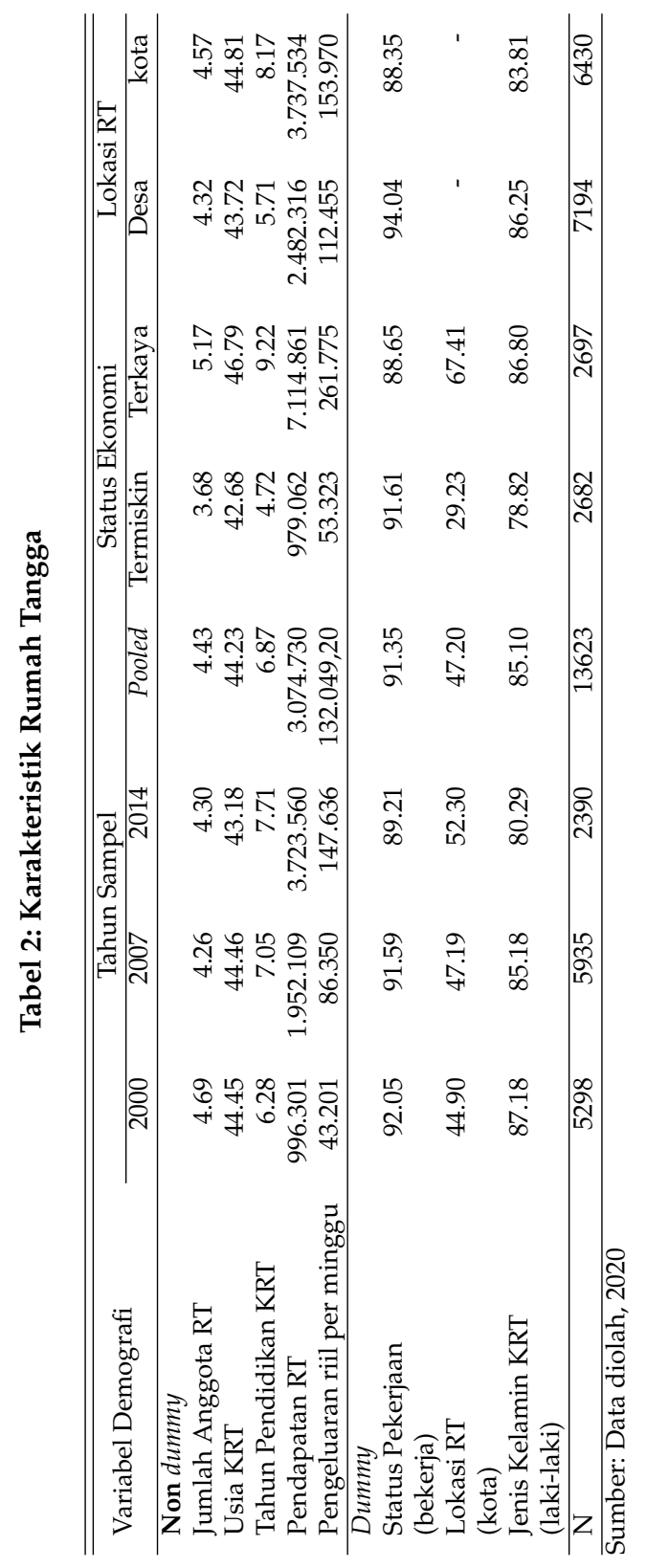


minyak goreng, gula, dan produk kedelai dibandingkan dengan daging. Hal itu dikarenakan harga daging yang terbilang cukup mahal sehingga rumah tangga termiskin lebih memilih untuk mengalokasian pengeluarannya membeli produk kedelai. Selain itu, ditemukan pula bahwa rumah tangga terkaya juga melakukan pengeluaran lebih banyak terhadap komoditas susu dan telur. Hal ini menunjukkan bahwa rumah tangga terkaya berusaha untuk memperoleh nutrisi berimbang pada sumber protein hewani dan nabati. Berbeda rumah tangga termiskin, karena keterbatasan kemampuan ekonomi, mereka hanya mampu memperoleh nutrisi yang bersumber dari protein nabati.

Tabel 3: Proporsi Pengeluaran Rumah Rangga

\begin{tabular}{lcccccccc}
\hline \hline \multirow{2}{*}{ Komoditas } & \multicolumn{3}{c}{ Tahun Sampel } & \multicolumn{2}{c}{ Status Ekonomi } & \multicolumn{2}{c}{ Lokasi RT } \\
\cline { 2 - 8 } & 2000 & 2007 & 2014 & Pooled & Termiskin & Terkaya & Desa & Kota \\
\hline Beras & 0.309 & 0.332 & 0.310 & 0.319 & 0.377 & 0.259 & 0.317 & 0.321 \\
Jagung & 0.012 & 0.011 & 0.013 & 0.011 & 0.013 & 0.012 & 0.012 & 0.011 \\
Minyak Goreng & 0.115 & 0.146 & 0.117 & 0.129 & 0.160 & 0.101 & 0.150 & 0.105 \\
Gula & 0.119 & 0.092 & 0.081 & 0.101 & 0.125 & 0.073 & 0.116 & 0.084 \\
Daging sapi & 0.047 & 0.024 & 0.022 & 0.032 & 0.009 & 0.069 & 0.028 & 0.038 \\
Daging ayam & 0.082 & 0.083 & 0.092 & 0.084 & 0.029 & 0.133 & 0.069 & 0.100 \\
Telur & 0.093 & 0.089 & 0.106 & 0.093 & 0.082 & 0.100 & 0.088 & 0.099 \\
Susu & 0.067 & 0.083 & 0.124 & 0.084 & 0.030 & 0.139 & 0.060 & 0.110 \\
Terigu & 0.028 & 0.024 & 0.024 & 0.025 & 0.022 & 0.027 & 0.029 & 0.022 \\
Produk kedelai & 0.126 & 0.114 & 0.109 & 0.117 & 0.149 & 0.085 & 0.127 & 0.106 \\
\hline N & 5298 & 5935 & 2390 & 13623 & 2682 & 2697 & 7194 & 6430 \\
\hline Sumber: Data diolah & 2020 & & & & & & &
\end{tabular}

Jika hasil yang ditemukan pada Tabel 2 dan 3 dikaitkan satu sama lain, maka dapat dikatakan bahwa makin besar pengeluaran suatu rumah tangga terhadap suatu komoditas, maka proporsi pengeluarannya akan makin kecil. Temuan ini mengonfirmasi teori ekonomi yang dikemukakan oleh Ernst Engel bahwa jika selera tidak berbeda, maka proporsi pengeluaran komoditas tertentu akan cenderung menurun seiring meningkatnya pendapatan (Walter, 2005).

Model estimasi QUAIDS (Lampiran 1) menunjukkan bahwa bentuk kuadrat pengeluaran pangan sebagian besar dari komoditas yang diteliti signifikan pada tingkat siginifikansi 1\%, kecuali pada komoditas terigu. Hal ini menunjukkan bahwa terdapat nonlinearitas kurva Engel pada total pengeluaran pada komoditas tersebut (Pangaribowo \& Tsegai, 2011). Jika parameter yang ditunjukkan pada hasil estimasi tidak signifikan, terdapat kemungkinan bahwa elastisitas pengeluaran pada konsumsi komoditas tersebut bersifat konstan di semua tingkat pendapatan (Mittal, 2010). Model QUAIDS juga mampu menunjukkan perubahan sifat suatu barang, baik dari barang normal menjadi barang mewah atau sebaliknya. Perubahan tersebut dapat dilihat dari nilai parameternya. Jika sebuah komoditas mempunyai nilai estimasi positif pada bentuk linearnya $(\beta /$ beta) namun memiliki nilai negatif pada bentuk kuadratnya $(\lambda /$ lambda), maka komoditas tersebut termasuk dalam barang mewah pada tingkat pengeluaran yang rendah dan menjadi barang pokok ketika tingkat pengeluaran tinggi (Banks et 
al., 1997). Berdasarkan hasil estimasi yang ditampilkan pada Lampiran 1, dalam penelitian ini tidak ada perubahan sifat komoditas tertentu antar waktu. Meskipun demikian, sifat komoditas tetap dapat ditunjukkan melalui hasil analisis dari estimasi nilai elastisitas pengeluaran.

Tabel 4 menampilkan post estimasi dari model yang digunakan, yaitu elastisitas pengeluaran. Nilai elastisitas pengeluaran sering dijadikan sebagai proksi dari elastisitas pendapatan. Nilai ini diperoleh dari perkalian antara rata-rata harga dari setiap komoditas dengan kuadrat pendapatan Engel serta variabel demografi yang digunakan. Sehingga temuan ini akan menjelaskan bagaimana sifat suatu komoditas bagi rumah tangga. Menurut Walter (2005), nilai elastisitas pendapatan yang bernilai kurang dari 1 menunjukkan bahwa komoditas tersebut merupakan barang normal, sedangkan yang bernilai lebih dari 1 menunjukkan bahwa komoditas tersebut merupakan barang mewah.

Tabel 4: Elastisitas Pendapatan

\begin{tabular}{|c|c|c|c|c|c|c|c|c|}
\hline \multirow{2}{*}{ Komoditas } & \multicolumn{4}{|c|}{ Tahun } & \multicolumn{2}{|c|}{ Status Ekonomi } & \multicolumn{2}{|c|}{ Lokasi RT } \\
\hline & 2000 & 2007 & 2014 & Pooled & Termiskin & Terkaya & Desa & Kota \\
\hline \multirow[t]{2}{*}{ Beras } & 1.341 & 1.347 & 1.436 & 1.369 & 1.369 & 1.374 & 1.393 & 1.319 \\
\hline & $(0.014)$ & $(0.012)$ & $(0.021)$ & $(0.009)$ & $(0.008)$ & $(0.013)$ & $(0.008)$ & $(0.010)$ \\
\hline \multirow[t]{2}{*}{ Jagung } & 1.011 & 0.787 & 0.634 & 0.858 & 0.929 & 0.805 & 0.899 & 0.787 \\
\hline & $(0.064)$ & $(0.065)$ & $(0.081)$ & $(0.040)$ & $(0.041)$ & $(0.054)$ & $(0.037)$ & $(0.058)$ \\
\hline \multirow[t]{2}{*}{ Minyak goreng } & 0.517 & 0.642 & 0.597 & 0.597 & 0.583 & 0.635 & 0.604 & 0.625 \\
\hline & $(0.016)$ & $(0.014)$ & $(0.026)$ & $(0.010)$ & $(0.009)$ & $(0.017)$ & $(0.008)$ & $(0.016)$ \\
\hline \multirow[t]{2}{*}{ Gula } & 0.514 & 0.522 & 0.549 & 0.508 & 0.558 & 0.405 & 0.555 & 0.457 \\
\hline & $(0.017)$ & $(0.018)$ & $(0.032)$ & $(0.012)$ & $(0.011)$ & $(0.023)$ & $(0.010)$ & (0.019) \\
\hline \multirow[t]{2}{*}{ Daging sapi } & 1.694 & 1.573 & 1.535 & 1.673 & 2.712 & 1.399 & 1.646 & 1.732 \\
\hline & $(0.037)$ & $(0.054)$ & $(0.095)$ & $(0.030)$ & $(0.114)$ & $(0.019)$ & $(0.035)$ & $(0.035)$ \\
\hline \multirow[t]{2}{*}{ Daging ayam } & 1.330 & 1.127 & 1.143 & 1.220 & 1.834 & 1.094 & 1.310 & 1.138 \\
\hline & $(0.026)$ & $(0.026)$ & $(0.036)$ & $(0.016)$ & $(0.055)$ & $(0.014)$ & $(0.019)$ & $(0.018)$ \\
\hline \multirow[t]{2}{*}{ Telur } & 0.818 & 0.681 & 0.577 & 0.703 & 0.780 & 0.620 & 0.765 & 0.619 \\
\hline & $(0.019)$ & $(0.020)$ & $(0.029)$ & $(0.013)$ & $(0.016)$ & $(0.016)$ & $(0.014)$ & $(0.016)$ \\
\hline \multirow[t]{2}{*}{ Susu } & 1.335 & 1.469 & 1.282 & 1.342 & 1.857 & 1.222 & 1.458 & 1.279 \\
\hline & $(0.031)$ & $(0.028)$ & $(0.037)$ & $(0.018)$ & $(0.056)$ & $(0.014)$ & $(0.025)$ & $(0.018)$ \\
\hline \multirow[t]{2}{*}{ Terigu } & 0.875 & 0.858 & 0.711 & 0.819 & 0.807 & 0.813 & 0.842 & 0.784 \\
\hline & $(0.040)$ & $(0.038)$ & $(0.064)$ & $(0.025)$ & $(0.034)$ & $(0.034)$ & $(0.022)$ & $(0.039)$ \\
\hline \multirow[t]{2}{*}{ Produk kedelai } & 0.569 & 0.574 & 0.492 & 0.558 & 0.588 & 0.502 & 0.567 & 0.573 \\
\hline & $(0.017)$ & $(0.016)$ & $(0.026)$ & $(0.011)$ & $(0.010)$ & $(0.021)$ & $(0.010)$ & $(0.016)$ \\
\hline
\end{tabular}

Sumber: Data diolah, 2020

Pada Tabel 4 menunjukkan bahwa seluruh komoditas mengalami peningkatan ketika terjadi kenaikan pendapatan rumah tangga, namun memiliki respons yang berbeda antara karakteristik rumah tangga. Beras merupakan barang mewah bagi seluruh rumah tangga, ketika rumah tangga mengalami kenaikan pendapatan sebesar 10\%, mereka akan meningkatkan alokasi konsumsi beras sebanyak 13\%. Selanjutnya komoditas yang memiliki elastisitas cukup besar adalah daging-dagingan, bagi seluruh rumah tangga komoditas daging merupakan barang mewah. Namun, terdapat perbedaan pada perubahan alokasi pada setiap rumah tangga, rumah tangga termiskin akan meningkatkan alokasi da- 
ging sapi sebanyak 27\% ketika mengalami peningkatan pendapatan sebesar $10 \%$. Sedangkan rumah tangga terkaya akan meningkatkan alokasinya hanya sebesar $14 \%$ ketika mengalami kenaikan pendapatan sebesar 10\%. Untuk rumah tangga berdasar karakteristik lokasi tidak mengalami perbedaan yang terlalu signifikan antara rumah tangga di daerah pedesaan dan perkotaan. Hal ini sejalan dengan penelitian yang dilakukan oleh (Hoang, 2009) bahwa di Vietnam, elastisitas pendapatan memiliki nilai yang positif. Artinya temuan ini mengonfirmasi bahwa negara berkembang seperti Vietnam dan Indonesia cenderung memiliki pola elastisitas pendapatan yang sama.

Hal yang sama ditemukan pada komoditas susu. Susu merupakan barang mewah bagi seluruh rumah tangga. Dalam kasus ini, rumah tangga termiskin mengalokasikan pengeluarannya terhadap susu ketika mengalami kenaikan pendapatan. Untuk komoditas lain seperti produk kedelai, gula, dan minyak goreng merupakan barang normal meskipun proporsi pengeluarannya cukup besar khususnya bagi keluarga termiskin, artinya kenaikan yang dialokasikan tidak sebesar persentase kenaikan pendapatan. Hasil temuan pada Tabel 4 mengindikasikan bahwa ketika rumah tangga mengalami kenaikan pendapatan, hal yang mereka lakukan adalah melakukan perbaikan asupan nutrisi khususnya bagi rumah tangga termiskin. Mereka membeli lebih makanan yang mengandung nutrisi seperti protein hewani dari daging-daginan, kalsium dari susu, serta meningkatkan konsumsi karbohidrat pada beras. Temuan ini sejalan dengan penelitian yang dilakukan oleh Pangaribowo \& Tsegai (2011) bahwa ketika rumah tangga mengalami peningkatan pendapatan mereka akan meningkatkan konsumsi yang komoditas yang bernutrisi.

Selanjutnya guna melihat respons rumah tangga terhadap perubahan harga yang terjadi pada komoditas itu sendiri menggunakan elastisitast harga sendiri. Elastisitas harga sendiri yang ditampilkan pada Tabel 5. Sesuai yang diharapkan, elastisitas harga sendiri yang ditampilkan menunjukan nilai negatif pada seluruh komoditas, artinya setiap kenaikan harga pada komoditas tersebut akan mendorong masyarakat untuk menurunkan konsumsinya. Temuan ini sejalan dengan teori permintaan yang menyatakan bahwa permintaan suatu barang akan menurun ketika terjadi kenaikan harga pada barang tersebut (Mankiw, 2001).

Elastisitas uncompensated dan compensated menunjukkan nilai yang berbeda namun memiliki pola yang sama. Nilai Hicksian lebih rendah dibanding Marshallian, hal ini dikarenakan permintaan Marshallian menggunakan efek subtitusi dan pendapatan sedangkan Hicksian hanya menggunakan efek subtitusi. Tabel 5 menunjukkan bahwa beberapa komoditas seperti jagung, daging sapi, daging ayam, telur, susu, terigu dan produk kedelai merupakan komoditas yang sangat responsif terhadap perubahan harga. Artinya ketika komoditas tersebut mengalami kenaikan harga sebesar 10\%, maka penurunan permintaan yang dilakukan rumah tangga akan melebihi dari 10\%. Seluruh rumah tangga dalam penelitian ini mengalami penurunan yang cukup tinggi dalam melakukan konsumsi ketika harga naik. Namun, dampak terbesar akibat naiknya kenaikan 
harga terjadi pada rumah tangga termiskin. Pasalnya alokasi terbesar mereka adalah beras dan produk kedelai, sehingga kenaikan harga akan menurukan konsumsi mereka yang nantinya dapat menurunkan jumlah asupan kalori dan protein. Hal tersebut tentunya akan berdampak buruk bagi kondisi kesehatan mereka, selain itu kemampuan mereka untuk bekerja menggunakan fisiknya akan berkurang jauh. Meskipun bagi rumah tangga terkaya dan rumah tangga di daerah perkotaan tidak terlalu terpapar efek dari perubahan harga, namun dapat dikatakan bahwa hampir seluruh rumah tangga akan mengurangi konsumsi "komoditas hewani" dengan persentase yang cukup besar. Temuan ini sejalan dengan Pangaribowo \& Tsegai (2011) dan Mittal (2010) yang menyatakan bahwa penurunan konsumsi pangan akan terjadi ketika harga komoditas tersebut meningkat.

Berbeda dengan elastisitas harga sendiri, elastisitas harga silang memiliki nilai elastisitas yang bervariasi. Hal ini menunjukkan bahwa dari analisis tersebut terdapat hubungan antara komoditas satu dengan lainnya yang saling menggantikan atau saling melengkapi. Pada Tabel 6 menampilkan hasil dari analisis elastisitas harga silang pada seluruh rumah tangga. Kenaikan harga beras mendorong turunnya konsumsi beberapa komoditas seperti gula, daging ayam, telur, susu dan terigu. Hal ini menandakan bahwa barang tersebut merupakan barang pelengkap atau koplementer terhadap beras. Di sisi lain, dengan meningkatnya harga beras akan meningkatkan konsumsi jagung, dan produk kedelai dengan persentase yang cukup tinggi. Artinya kedua barang tersebut menggantikan beras dalam pemenuhan kalori atau dapat disebut sebagai subtitusi. Selain beras, komoditas yang menyebabkan penuruan cukup banyak terhadap konsumsi komoditas lain adalah gula, dengan meningkatnya harga gula akan mengurangi konsumsi beras, jagung, minyak goreng, daging ayam, susu dan terigu. Efek terbesar dalam peningkatan ini terdapat pada jagung, setiap kenaikan harga gula $10 \%$ menyebabkan penurunan konsumsi jagung sebanyak $14 \%$.

Beberapa komoditas mengurangi konsumsi beras ketika harganya naik, artinya barang ini saling melengkapi dalam konsumsi terhadap beras seperti gula, daging ayam, telur, susu terigu dan produk kedelai. Kenaikan pada komoditas ini perlu ditanggapi serius karena dengan naiknya harga pada komoditas tersebut akan menyebabkan penurunan konsumsi beras. Seperti yang kita ketahui bahwa beras merupakan sumber kalori dan karbohidrat utama pada mayoritas masyarakat di Indonesia, sehingga menurunnya konsumsi beras dimasyarakat memiliki efek yang cukup besar pada asupan nutrisi tersebut. Selain itu, beras merupakan komoditas dengan nilai ekonomi terbesar di Indonesia. Kelesuan terhadap konsumsi beras dapat mengubah perekonomian di Indonesia khususnya dari sisi konsumsi.

\section{Kesimpulan}

Penelitian ini bertujuan untuk menganalisis pola konsumsi rumah tangga di Indonesia terhadap permintaan kebutuhan pangan pokok. Data yang digunakan 
Tabel 5: Elastisitas Harga Sendiri

\begin{tabular}{|c|c|c|c|c|c|c|c|c|}
\hline Komoditas & 2000 & 2007 & 2014 & Pooled & Terkaya & Termiskin & Desa & Kota \\
\hline \multicolumn{9}{|c|}{ Uncompensated / Marshallian } \\
\hline \multirow[t]{2}{*}{ Beras } & -0.783 & -0.960 & -1.008 & -1.052 & -0.886 & -1.180 & -1.155 & -0.921 \\
\hline & $(0.087)$ & $(0.085)$ & $(0.141)$ & $(0.037)$ & $(0.051)$ & $(0.036)$ & $(0.041)$ & $(0.041)$ \\
\hline \multirow[t]{2}{*}{ Jagung } & -2.355 & -0.433 & -0.967 & -1.077 & -1.071 & -1.070 & $(-1.074)$ & $(-1.081)$ \\
\hline & $(0.301)$ & $(0.304)$ & $(0.263)$ & $(0.160)$ & $(0.154)$ & $(0.141)$ & $(0.150)$ & $(0.174)$ \\
\hline \multirow[t]{2}{*}{ Minyak goreng } & -0.828 & -1.028 & -1.001 & -0.682 & -0.506 & -0.807 & -0.766 & -0.535 \\
\hline & $(0.074)$ & $(0.074)$ & $(0.147)$ & $(0.031)$ & $(0.042)$ & $(0.027)$ & $(0.028)$ & $(0.040)$ \\
\hline \multirow[t]{2}{*}{ Gula } & -0.669 & -0.144 & -1.155 & -0.554 & -0.367 & -0.654 & -0.623 & -0.448 \\
\hline & $(0.152)$ & (0.193) & $(0.286)$ & $(0.096)$ & $(0.133)$ & $(0.078)$ & $(0.084)$ & $(0.116)$ \\
\hline \multirow[t]{2}{*}{ Daging sapi } & -3.474 & -2.644 & -4.397 & -3.095 & -1.995 & -8.033 & -3.407 & -2.825 \\
\hline & $(0.229)$ & (0.319) & $(0.757)$ & $(0.173)$ & $(0.083)$ & $(0.574)$ & (0.199) & $(0.152)$ \\
\hline \multirow[t]{2}{*}{ Daging ayam } & -1.240 & -1.090 & -0.660 & -0.996 & -0.988 & -1.033 & -1.006 & -0.986 \\
\hline & $(0.121)$ & (0.123) & $(0.205)$ & $(0.069)$ & $(0.043)$ & $(0.201)$ & $(0.084)$ & $(0.058)$ \\
\hline \multirow[t]{2}{*}{ Telur } & -0.739 & -0.296 & -1.620 & -0.986 & -0.967 & -1.015 & -0.984 & -0.980 \\
\hline & $(0.120)$ & $(0.131)$ & (0.309) & $(0.053)$ & $(0.050)$ & $(0.061)$ & $(0.056)$ & $(0.051)$ \\
\hline \multirow[t]{2}{*}{ Susu } & -0.942 & -0.984 & -0.820 & -1.176 & -1.101 & -1.509 & -1.256 & -1.129 \\
\hline & (0.106) & $(0.076)$ & $(0.205)$ & $(0.048)$ & $(0.029)$ & $(0.132)$ & $(0.067)$ & $(0.037)$ \\
\hline \multirow[t]{2}{*}{ Terigu } & -1.287 & -1.194 & -1.101 & -1.314 & -1.302 & -1.361 & -1.280 & -1.364 \\
\hline & (0.190) & $(0.234)$ & $(0.315)$ & $(0.113)$ & $(0.108)$ & $(0.130)$ & $(0.101)$ & $(0.131)$ \\
\hline \multirow[t]{2}{*}{ Produk Kedelai } & -1.195 & -1.392 & -1.247 & -1.310 & -1.377 & -1.277 & -1.316 & -1.301 \\
\hline & $(0.054)$ & $(0.043)$ & $(0.103)$ & $(0.032)$ & $(0.044)$ & $(0.026)$ & $(0.030)$ & $(0.036)$ \\
\hline \multicolumn{9}{|c|}{ Compensated / Hicksian } \\
\hline \multirow[t]{2}{*}{ Beras } & -0.368 & -0.511 & -0.563 & -0.614 & -0.529 & -0.663 & -0.712 & -0.496 \\
\hline & $(0.086)$ & $(0.085)$ & $(0.140)$ & $(0.037)$ & $(0.050)$ & $(0.035)$ & $(0.040)$ & $(0.040)$ \\
\hline \multirow[t]{2}{*}{ Jagung } & -2.342 & -0.425 & -0.958 & -1.067 & -1.061 & -1.058 & -1.062 & -1.073 \\
\hline & $(0.301)$ & $(0.304)$ & $(0.263)$ & $(0.160)$ & $(0.154)$ & $(0.141)$ & $(0.150)$ & $(0.174)$ \\
\hline \multirow[t]{2}{*}{ Minyak goreng } & -0.769 & -0.933 & -0.931 & -0.604 & -0.442 & -0.713 & -0.675 & -0.469 \\
\hline & $(0.074)$ & $(0.074)$ & $(0.147)$ & $(0.031)$ & $(0.042)$ & $(0.027)$ & $(0.028)$ & $(0.041)$ \\
\hline \multirow[t]{2}{*}{ Gula } & -0.608 & -0.096 & -1.111 & -0.503 & -0.338 & -0.584 & -0.558 & -0.409 \\
\hline & (0.152) & (0.193) & $(0.286)$ & (0.096) & $(0.133)$ & (0.078) & $(0.084)$ & (0.116) \\
\hline \multirow[t]{2}{*}{ Daging sapi } & -3.393 & -2.606 & -4.363 & -3.040 & -1.899 & -8.006 & -3.359 & -2.759 \\
\hline & $(0.229)$ & $(0.319)$ & $(0.757)$ & (0.173) & $(0.083)$ & (0.574) & $(0.199)$ & $(0.152)$ \\
\hline \multirow[t]{2}{*}{ Daging ayam } & -1.131 & -0.997 & -0.554 & -0.894 & -0.843 & -0.980 & -0.915 & -0.871 \\
\hline & $(0.121)$ & (0.123) & $(0.205)$ & $(0.069)$ & $(0.043)$ & $(0.201)$ & $(0.084)$ & $(0.058)$ \\
\hline \multirow[t]{2}{*}{ Telur } & -0.662 & -0.236 & -1.559 & -0.920 & -0.905 & -0.951 & -0.916 & -0.918 \\
\hline & $(0.120)$ & $(0.131)$ & $(0.309)$ & $(0.053)$ & $(0.050)$ & $(0.061)$ & $(0.056)$ & $(0.051)$ \\
\hline \multirow[t]{2}{*}{ Susu } & -0.853 & -0.863 & -0.660 & -1.064 & -0.930 & -1.452 & -1.168 & -0.988 \\
\hline & $(0.105)$ & $(0.076)$ & $(0.205)$ & $(0.048)$ & $(0.029)$ & $(0.132)$ & $(0.067)$ & (0.037) \\
\hline \multirow[t]{2}{*}{ Terigu } & -1.262 & -1.173 & -1.084 & -1.292 & -1.280 & -1.343 & -1.256 & -1.346 \\
\hline & $(0.190)$ & $(0.234)$ & $(0.315)$ & $(0.113)$ & $(0.108)$ & $(0.130)$ & $(0.101)$ & $(0.131)$ \\
\hline \multirow[t]{2}{*}{ Produk Kedelai } & -1.123 & -1.327 & -1.194 & -1.245 & -1.334 & -1.190 & -1.244 & -1.240 \\
\hline & $(0.054)$ & $(0.043)$ & (0.103) & $(0.031)$ & $(0.044)$ & $(0.026)$ & $(0.030)$ & $(0.036)$ \\
\hline
\end{tabular}

Sumber: Data diolah, 2020 
Tabel 6: Elastisitas Harga Silang

\begin{tabular}{|c|c|c|c|c|c|c|c|c|c|c|}
\hline Komoditas & Beras & Jagung & $\begin{array}{l}\text { Minyak } \\
\text { Goreng }\end{array}$ & Gula & $\begin{array}{c}\text { Daging } \\
\text { Sapi }\end{array}$ & $\begin{array}{c}\text { Daging } \\
\text { Ayam }\end{array}$ & Telur & Susu & Terigu & $\begin{array}{l}\text { Produk } \\
\text { Kedelai }\end{array}$ \\
\hline \multicolumn{11}{|c|}{ Uncompensated / Marshallian } \\
\hline Beras & & $\begin{array}{c}0.013 \\
(0.016)\end{array}$ & $\begin{array}{c}0.017 \\
(0.021)\end{array}$ & $\begin{array}{l}-0.147 \\
(0.017)\end{array}$ & $\begin{array}{c}0.013 \\
(0.018)\end{array}$ & $\begin{array}{l}-0.067 \\
(0.017)\end{array}$ & $\begin{array}{l}-0.076 \\
(0.016)\end{array}$ & $\begin{array}{l}-0.009 \\
(0.011)\end{array}$ & $\begin{array}{l}-0.045 \\
(0.008)\end{array}$ & $\begin{array}{l}-0.015 \\
(0.015)\end{array}$ \\
\hline Jagung & $\begin{array}{c}0.511 \\
(0.228)\end{array}$ & & $\begin{array}{l}0.032 \\
(0.14)\end{array}$ & $\begin{array}{l}-1.476 \\
(0.258)\end{array}$ & $\begin{array}{c}0.441 \\
(0.194)\end{array}$ & $\begin{array}{c}0.849 \\
(0.172)\end{array}$ & $\begin{array}{l}-0.148 \\
(0.171)\end{array}$ & $\begin{array}{c}0.076 \\
(0.117)\end{array}$ & $\begin{array}{l}-0.183 \\
(0.228)\end{array}$ & $\begin{array}{c}0.116 \\
(0.113)\end{array}$ \\
\hline $\begin{array}{l}\text { Minyak } \\
\text { goreng }\end{array}$ & $\begin{array}{c}0.284 \\
(0.041)\end{array}$ & $\begin{array}{c}0.006 \\
(0.013)\end{array}$ & & $\begin{array}{l}-0.101 \\
(0.031)\end{array}$ & $\begin{array}{l}-0.133 \\
(0.024)\end{array}$ & $\begin{array}{c}0.008 \\
(0.026)\end{array}$ & $\begin{array}{c}-0.092 \\
(0.024)\end{array}$ & $\begin{array}{c}0.029 \\
(0.022)\end{array}$ & $\begin{array}{c}0.030 \\
(0.041)\end{array}$ & $\begin{array}{c}0.053 \\
(0.021)\end{array}$ \\
\hline Gula & $\begin{array}{l}-0.188 \\
(0.067)\end{array}$ & $\begin{array}{l}-0.169 \\
(0.03)\end{array}$ & $\begin{array}{l}-0.121 \\
(0.039)\end{array}$ & & $\begin{array}{c}0.143 \\
(0.054)\end{array}$ & $\begin{array}{l}-0.098 \\
(0.049)\end{array}$ & $\begin{array}{c}0.340 \\
(0.049)\end{array}$ & $\begin{array}{c}0.032 \\
(0.034)\end{array}$ & $\begin{array}{l}-0.015 \\
(0.067)\end{array}$ & $\begin{array}{c}0.122 \\
(0.033)\end{array}$ \\
\hline $\begin{array}{l}\text { Daging } \\
\text { sapi }\end{array}$ & $\begin{array}{c}0.007 \\
(0.168)\end{array}$ & $\begin{array}{l}0.148 \\
(0.07)\end{array}$ & $\begin{array}{l}-0.650 \\
(0.094)\end{array}$ & $\begin{array}{c}0.326 \\
(0.165)\end{array}$ & & $\begin{array}{c}0.642 \\
(0.117)\end{array}$ & $\begin{array}{c}0.321 \\
(0.113)\end{array}$ & $\begin{array}{c}0.129 \\
(0.083)\end{array}$ & $\begin{array}{c}0.410 \\
(0.168)\end{array}$ & $\begin{array}{c}0.088 \\
(0.081)\end{array}$ \\
\hline $\begin{array}{r}\text { Daging } \\
\text { ayam }\end{array}$ & $\begin{array}{l}-0.206 \\
(0.069)\end{array}$ & $\begin{array}{c}0.115 \\
(0.024)\end{array}$ & $\begin{array}{c}-0.068 \\
(0.041)\end{array}$ & $\begin{array}{l}-0.192 \\
(0.059)\end{array}$ & $\begin{array}{c}0.269 \\
(0.046)\end{array}$ & & $\begin{array}{l}-0.149 \\
(0.048)\end{array}$ & $\begin{array}{l}-0.002 \\
(0.04)\end{array}$ & $\begin{array}{l}-0.117 \\
(0.069)\end{array}$ & $\begin{array}{c}0.125 \\
(0.038)\end{array}$ \\
\hline Telur & $\begin{array}{l}-0.034 \\
(0.057)\end{array}$ & $\begin{array}{l}-0.017 \\
(0.022)\end{array}$ & $\begin{array}{l}-0.146 \\
(0.033)\end{array}$ & $\begin{array}{c}0.341 \\
(0.052)\end{array}$ & $\begin{array}{l}0.146 \\
(0.04)\end{array}$ & $\begin{array}{l}-0.087 \\
(0.043)\end{array}$ & & $\begin{array}{l}-0.056 \\
(0.033)\end{array}$ & $\begin{array}{c}0.126 \\
(0.057)\end{array}$ & $\begin{array}{c}0.011 \\
(0.030)\end{array}$ \\
\hline Susu & $\begin{array}{l}-0.031 \\
(0.06)\end{array}$ & $\begin{array}{c}0.005 \\
(0.017)\end{array}$ & $\begin{array}{l}-0.048 \\
(0.034)\end{array}$ & $\begin{array}{l}-0.044 \\
(0.041)\end{array}$ & $\begin{array}{c}0.063 \\
(0.033)\end{array}$ & $\begin{array}{l}-0.014 \\
(0.04)\end{array}$ & $\begin{array}{l}-0.125 \\
(0.037)\end{array}$ & & $\begin{array}{c}0.010 \\
(0.022)\end{array}$ & $\begin{array}{c}0.018 \\
(0.033)\end{array}$ \\
\hline Terigu & $\begin{array}{l}-0.371 \\
(0.135)\end{array}$ & $\begin{array}{l}-0.083 \\
(0.064)\end{array}$ & $\begin{array}{c}0.119 \\
(0.095)\end{array}$ & $\begin{array}{l}-0.090 \\
(0.146)\end{array}$ & $\begin{array}{c}0.550 \\
(0.111)\end{array}$ & $\begin{array}{l}-0.344 \\
(0.102)\end{array}$ & $\begin{array}{c}0.445 \\
(0.102)\end{array}$ & $\begin{array}{c}0.076 \\
(0.071)\end{array}$ & & $\begin{array}{c}0.192 \\
(0.069)\end{array}$ \\
\hline $\begin{array}{l}\text { Produk } \\
\text { Kedelai }\end{array}$ & $\begin{array}{c}0.218 \\
(0.041)\end{array}$ & $\begin{array}{c}0.015 \\
(0.011)\end{array}$ & $\begin{array}{c}0.061 \\
(0.023)\end{array}$ & $\begin{array}{c}0.100 \\
(0.028)\end{array}$ & $\begin{array}{c}0.059 \\
(0.023) \\
\end{array}$ & $\begin{array}{c}0.146 \\
(0.027)\end{array}$ & $\begin{array}{c}0.026 \\
(0.024) \\
\end{array}$ & $\begin{array}{c}0.077 \\
(0.023)\end{array}$ & $\begin{array}{c}0.050 \\
(0.015) \\
\end{array}$ & \\
\hline Compensated & Hicksian & & & & & & & & & \\
\hline Beras & & $\begin{array}{c}0.029 \\
(0.008)\end{array}$ & $\begin{array}{c}0.194 \\
(0.016)\end{array}$ & $\begin{array}{c}-0.008 \\
(0.021)\end{array}$ & $\begin{array}{c}0.058 \\
(0.017)\end{array}$ & $\begin{array}{c}0.048 \\
(0.018)\end{array}$ & $\begin{array}{c}0.053 \\
(0.017)\end{array}$ & $\begin{array}{c}0.105 \\
(0.016)\end{array}$ & $\begin{array}{l}-0.009 \\
(0.011)\end{array}$ & $\begin{array}{c}0.146 \\
(0.015)\end{array}$ \\
\hline Jagung & $\begin{array}{c}0.786 \\
(0.227)\end{array}$ & & $\begin{array}{l}0.143 \\
(0.14)\end{array}$ & $\begin{array}{l}-1.390 \\
(0.258)\end{array}$ & $\begin{array}{c}0.469 \\
(0.194)\end{array}$ & $\begin{array}{c}0.921 \\
(0.172)\end{array}$ & $\begin{array}{l}-0.067 \\
(0.171)\end{array}$ & $\begin{array}{c}0.148 \\
(0.117)\end{array}$ & $\begin{array}{l}-0.161 \\
(0.14)\end{array}$ & $\begin{array}{c}0.217 \\
(0.113)\end{array}$ \\
\hline $\begin{array}{l}\text { Minyak } \\
\text { goreng }\end{array}$ & $\begin{array}{c}0.475 \\
(0.041)\end{array}$ & $\begin{array}{c}0.013 \\
(0.013)\end{array}$ & & $\begin{array}{l}-0.040 \\
(0.031)\end{array}$ & $\begin{array}{l}-0.114 \\
(0.024)\end{array}$ & $\begin{array}{c}0.058 \\
(0.026)\end{array}$ & $\begin{array}{l}-0.035 \\
(0.024)\end{array}$ & $\begin{array}{c}0.079 \\
(0.022)\end{array}$ & $\begin{array}{c}0.045 \\
(0.019)\end{array}$ & $\begin{array}{c}0.123 \\
(0.021)\end{array}$ \\
\hline Gula & $\begin{array}{l}-0.025 \\
(0.067)\end{array}$ & $\begin{array}{l}-0.163 \\
(0.03)\end{array}$ & $\begin{array}{l}-0.055 \\
(0.039)\end{array}$ & & $\begin{array}{c}0.160 \\
(0.054)\end{array}$ & $\begin{array}{l}-0.056 \\
(0.049)\end{array}$ & $\begin{array}{c}0.387 \\
(0.049)\end{array}$ & $\begin{array}{c}0.075 \\
(0.034)\end{array}$ & $\begin{array}{c}-0.002 \\
(0.038)\end{array}$ & $\begin{array}{c}0.182 \\
(0.033)\end{array}$ \\
\hline $\begin{array}{l}\text { Daging } \\
\text { sapi }\end{array}$ & $\begin{array}{c}0.543 \\
(0.167)\end{array}$ & $\begin{array}{l}0.168 \\
(0.07)\end{array}$ & $\begin{array}{l}-0.433 \\
(0.094)\end{array}$ & $\begin{array}{c}0.495 \\
(0.165)\end{array}$ & & $\begin{array}{c}0.783 \\
(0.117)\end{array}$ & $\begin{array}{c}0.478 \\
(0.113)\end{array}$ & $\begin{array}{c}0.269 \\
(0.083)\end{array}$ & $\begin{array}{c}0.454 \\
(0.087)\end{array}$ & $\begin{array}{c}0.285 \\
(0.081)\end{array}$ \\
\hline $\begin{array}{r}\text { Daging } \\
\text { ayam }\end{array}$ & $\begin{array}{c}0.184 \\
(0.069)\end{array}$ & $\begin{array}{c}0.130 \\
(0.024)\end{array}$ & $\begin{array}{c}0.090 \\
(0.041)\end{array}$ & $\begin{array}{l}-0.068 \\
(0.059)\end{array}$ & $\begin{array}{c}0.310 \\
(0.046)\end{array}$ & & $\begin{array}{l}-0.034 \\
(0.049)\end{array}$ & $\begin{array}{l}0.100 \\
(0.04)\end{array}$ & $\begin{array}{l}-0.085 \\
(0.032)\end{array}$ & $\begin{array}{c}0.269 \\
(0.038)\end{array}$ \\
\hline Telur & $\begin{array}{c}0.191 \\
(0.057)\end{array}$ & $\begin{array}{l}-0.008 \\
(0.022)\end{array}$ & $\begin{array}{l}-0.055 \\
(0.033)\end{array}$ & $\begin{array}{c}0.412 \\
(0.052)\end{array}$ & $\begin{array}{l}0.169 \\
(0.04)\end{array}$ & $\begin{array}{c}-0.028 \\
(0.043)\end{array}$ & & $\begin{array}{c}0.003 \\
(0.033)\end{array}$ & $\begin{array}{c}0.144 \\
(0.028)\end{array}$ & $\begin{array}{l}0.093 \\
(0.03)\end{array}$ \\
\hline Susu & $\begin{array}{c}0.399 \\
(0.059)\end{array}$ & $\begin{array}{c}0.021 \\
(0.017)\end{array}$ & $\begin{array}{c}0.126 \\
(0.034)\end{array}$ & $\begin{array}{c}0.092 \\
(0.041)\end{array}$ & $\begin{array}{c}0.107 \\
(0.033)\end{array}$ & $\begin{array}{l}0.099 \\
(0.04)\end{array}$ & $\begin{array}{c}0.001 \\
(0.037)\end{array}$ & & $\begin{array}{c}0.045 \\
(0.022)\end{array}$ & $\begin{array}{c}0.175 \\
(0.033)\end{array}$ \\
\hline Terigu & $\begin{array}{l}-0.108 \\
(0.135)\end{array}$ & $\begin{array}{l}-0.073 \\
(0.064)\end{array}$ & $\begin{array}{c}0.225 \\
(0.095)\end{array}$ & $\begin{array}{l}-0.008 \\
(0.146)\end{array}$ & $\begin{array}{c}0.577 \\
(0.111)\end{array}$ & $\begin{array}{l}-0.275 \\
(0.102)\end{array}$ & $\begin{array}{c}0.522 \\
(0.102)\end{array}$ & $\begin{array}{c}0.145 \\
(0.071)\end{array}$ & & $\begin{array}{c}0.289 \\
(0.069)\end{array}$ \\
\hline $\begin{array}{l}\text { Produk } \\
\text { Kedelai }\end{array}$ & $\begin{array}{l}0.397 \\
(0.04)\end{array}$ & $\begin{array}{c}0.022 \\
(0.011)\end{array}$ & $\begin{array}{c}0.133 \\
(0.023)\end{array}$ & $\begin{array}{c}0.157 \\
(0.028)\end{array}$ & $\begin{array}{c}0.078 \\
(0.023)\end{array}$ & $\begin{array}{c}0.193 \\
(0.027)\end{array}$ & $\begin{array}{c}0.079 \\
(0.024)\end{array}$ & $\begin{array}{c}0.123 \\
(0.023)\end{array}$ & $\begin{array}{c}0.064 \\
(0.015)\end{array}$ & \\
\hline
\end{tabular}

Sumber: Data diolah, 2020

dalam penelitian ini merupakan data pooled cross section dengan rentang waktu antara tahun 2000 hingga tahun 2014 yang bersumber dari Indonesian Family Life Survey. Sebanyak 13.623 rumah tangga memenuhi kriteria untuk dijadikan sampel pada penelitian ini. Dari analisis yang telah dilakukan, dapat ditarik kesimpulan sebagai berikut.

1. Dari analisis yang telah dilakukan menggunakan model QUAIDS, terdapat pola nonlinearitas kurva engel pada total pengeluaran seluruh komoditas dalam penelitian. Selain itu, hasil estimasi QUAIDS juga menunjukkan bahwa tidak ada perubahan sifat komoditas tertentu antar waktu yang ditunjukkan dengan tidak terpenuhinya syarat nilai estimasi positif pada 
bentuk linear dan nilai estimasi negatif pada bentuk kuadratnya.

2. Pola konsumsi bahan pangan pokok di Indonesia masih di dominasi oleh beras. Selebihnya bagi rumah tangga termiskin disusul dengan konsumsi gula, minyak goreng dan produk kedelai. Sedangkan bagi rumah tangga terkaya prioritas kedua mereka selain beras merukan produk hewani berupa telur, daging ayam dan susu.

3. Ketika pendapatan rumah tangga meningkat, seluruh rumah tangga cenderung meningkatkan sebagian besar konsumsi mereka pada komoditas yang memberikan nilai gizi tinggi seperti telur, daging ayam, daging sapi dan susu. Namun di sisi lain, ketika terjadi kenaikan harga, komoditas pangan hewani mengalami penurunan konsumsi yang cukup besar bagi seluruh rumah tangga. Hal yang sama juga terjadi pada kedelai sebagai, penurunan pada komoditas produk kedelai memiliki efek yang cukup buruk untuk rumah tangga termiskin, pasalnya prioritas pembelian mereka selain beras adalah produk kedelai, sehingga saat terjadi kenaikan harga dan konsumsi mereka menurun akan diikuti penuruna asupan gizi bagi mereka.

4. Beberapa komoditas sangat responsif terhadap perubahan harga pada komoditas lainnya. Seperti kenaikan beras yang mengakibatkan mayoritas konsumsi pangan ikut menurun. Selain itu, gula juga mengalami hal yang serupa, dimana kenaikan komoditas gula akan menurunkan berbagai komoditas lainnya. Hal yang perlu diperhatikan khusus adalah, beberapa kenaikan harga komoditas seperti daging ayam, telur, susu, terigu dan produk kedelai memicu penurunan komoditas beras. Sehingga penurunan ini mengakibatkan dampak serius yang dapat mengurangi asupan gizi di masyarakat.

\subsection{Implikasi Kebijakan}

Berdasarkan hasil penelitian yang telah dilakukan, terdapat beberapa implikasi kebijakan yang dapat diajukan oleh peneliti sebagai berikut.

1. Berdasarkan nilai elastisitas yang ditemukan, salah satu upaya yang dapat dilakukan untuk menstabilkan konsumsi di masyarakat adalah dengan melakukan stabilisasi harga. Untuk mewujudkan hal itu, pemerintah dapat melakukan operasi pasar secara rutin untuk mengawasi adanya kecurangan baik dari segi mark-up harga maupun penimbunan pangan. Selain itu pemerintah dapat melakukan pengawasan terhadap stabilisasi ketika panen raya yang sering terjadi penurunan harga secara signifikan pada masa tersebut. Hal ini menjadi sangat krusial karena hasil temuan yang telah dilakukan menunjukkan ketika terjadi perubahan harga pada suatu komoditas, penurunan konsumsi yang terjadi melebihi persentase kenaikan harga tersebut. Sehingga ditakutkan ketika konsumsi menurun, akan menyebabkan menurunnya angka asupan gizi di masyarakat.

2. Peningkatan pendapatan di masyarakat berdampak baik terhadap kenaikan konsumsi yang dilakukan khususnya masyarakat miskin. Apabila 
pemerintah berupaya untuk memperbaiki pola konsumsi dan nutrisi masyarakat, maka peningkatan pendapatan melalui berbagai jenis bantuan dapat dilakukan.

3. Konsumsi komoditas hewani nampaknya masih cukup rendah. Hal ini sangat krusial mengingat kebutuhan sumber protein terbesar berasal dari komoditas pangan hewani baik telur, susu, daging ayam dan daging sapi. Kontrol harga sangat diperlukan sehingga masyarakat luas mampu memperoleh komoditas hewani dengan harga yang cukup terjangkau. Untuk itu, perlu adanya program intervensi dari pemerintah yang menguatkan usaha ternak, seperti penguatan subsidi pakan, dan pendidikan mengenai penggemukan ternak sapi, sehingga kebutuhan daging sapi mampu terpenuhi dan diharapkan mampu menurunkan harga daging sapi yang terbilang cukup mahal.

\section{Daftar Pustaka}

[1] Alexandri, C., Păuna, B., \& Luca, L. (2015). An estimation of food demand system in Romania-implications for population's food security. Procedia Economics and Finance, 22, 577-586. doi: https://doi.org/10.1016/s2212-5671(15)00263-4.

[2] Badan Pusat Statistik. (2019). Produk Domestik Bruto Indonesia menurut pengeluaran 2014-2018.

[3] Banks, J., Blundell, R., \& Lewbel, A. (1997). Quadratic Engel curves and consumer demand. Review of Economics and Statistics, 79(4), 527-539. doi: https://doi.org/10.1162/003465397557015.

[4] Borton, J., \& Shoham, J. (1991). Mapping vulnerability to food insecurity: Tentative guidelines for WFP offices. Study commissioned by the World Food Programme. London: Relief and Development Institute.

[5] Braun, J. V. (Ed.) (1995). Employment for poverty reduction and food security. International Food Policy Research Institute.

[6] Cranfield, J. A., Eales, J. S., Hertel, T. W., \& Preckel, P. V. (2003). Model selection when estimating and predicting consumer demands using international, cross section data. Empirical Economics, 28(2), 353-364. doi: https://doi.org/10.1007/s001810200135.

[7] Denton, J. A. (1990). Society and the official world: A reintroduction to sociology. General Hall.

[8] Dona, M. N. L., Zivkovic, S., Lange, K., \& Chidmi, B. (2018). Household food consumption and demand for nutrients in Sri Lanka. Selected Paper prepared for presentation at the Southern Agricultural Economics Annual Meeting, Jacksonville, Florida, February, 3-6 2018.

[9] Dunne, J. P., \& Edkins, B. (2008). The demand for food in South Africa. South African Journal of Economics, 76(1), 104-117. doi: https://doi.org/10.1111/j.18136982.2008.00162.x.

[10] Faharuddin, Yunita, Mulyana, A., \& Yamin, M. (2019). Agricultural households' food demand: Evidence from Indonesia. Asian Journal of Agriculture and Development, 16(2), 45-60. https://doi.org/10.37801/ajad2019.16.2.3.

[11] Hoang, L. V. (2009). Estimantion of food demand from household survey data in Vietnam. Depocen Working Paper Series 2009/12. Development and Policies Research Center (DEPOCEN). Diakses pada 26 
Oktober 2019. http://depocenwp.org/upload/pubs/VuHoangLinh/ EstimationofFoodDemandfromHouseholdSurveyDatainVietnam_DEPOCENWP. pdf.

[12] Kementrian Perdagangan Republik Indonesia. (2014). Rencana strategis Kementerian Perdagangan 2010-2014.

[13] Le, C. Q. (2008). An empirical study of food demand in Vietnam. ASEAN Economic Bulletin, 25(3), 283-292.

[14] Levy, P. S., \& Lemeshow, S. (2008). Sampling of populations: Methods and applications (4th Edition). John Wiley \& Sons, Inc.

[15] Mankiw, N. G. (2001). Principle of microeconomics (2nd Edition). Harcourt College Publisher.

[16] Mittal, S. (2010). Application of the QUAIDS model to the food sector in India. Journal of Quantitative Economics, 8(1), 42-54.

[17] Olubukunmi, O. O., Kayode, S. K., Mistura, R. A., Yewande, D. A., \& Adebayo, O. (2016). Food and non-food expenditure differential across poor and non-poor households in South-East Nigeria. International Journal of Scientific $\mathcal{E}$ Engineering Research, 7(1), 150-160.

[18] Pangaribowo, E. H., \& Tsegai, D. W. (2011). Food demand analysis of Indonesian households with particular attention to the poorest. ZEF-Discussion Papers on Development Policy, 151. Zentrum für Entwicklungsforschung (ZEF) The Center for Development Research, University of Bonn. Diakses pada 26 Oktober 2019 dari https://www.zef.de/fileadmin/user_upload/zef_dp_151.pdf.

[19] Strauss, J., Witoelar, F., \& Sikoki, B. (2016). The fifth wave of the Indonesia Family Life Survey: Overview and field report, Volume 1. Working Paper WR-1143/1-NIA/NICHD. RAND Corporation. doi: https://doi.org/10.7249/WR1143.1.

[20] Walter, N. (2005). Microeconomic theory: Basic principles and extensions (8th Edition). South-Western College Pub. 


\section{Lampiran}

\section{Output Model Quadratic Almost Ideal Demand System (QUAI- DS)}

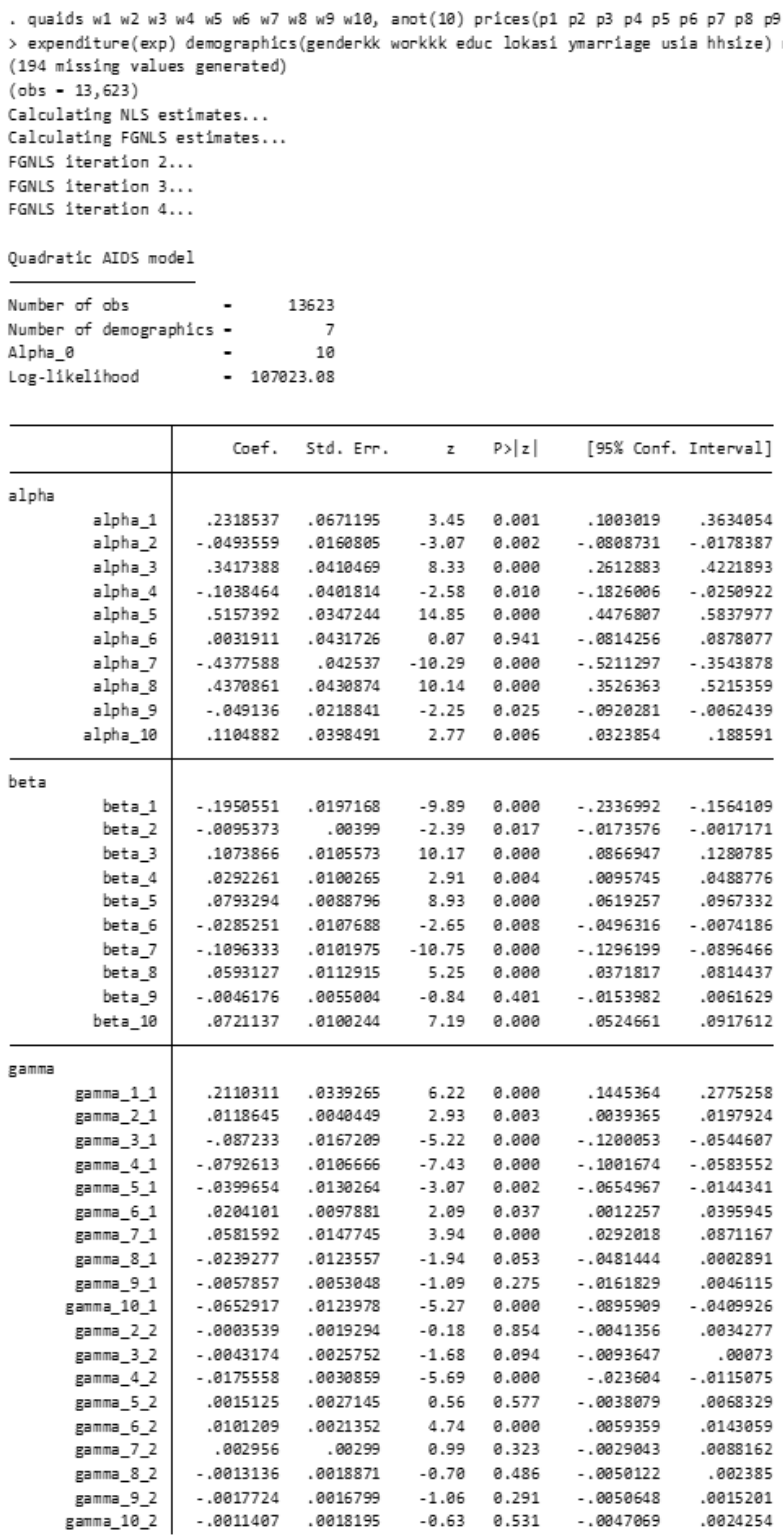




\begin{tabular}{|c|c|c|c|c|c|c|}
\hline gamma_3_3 & .096556 & .0111968 & 8.62 & 0.000 & .0746108 & .1185013 \\
\hline gamma_4_3 & .0053664 & .0063047 & 0.85 & 0.395 & -.0069907 & .0177234 \\
\hline gamma_5_3 & .0136226 & .0069765 & 1.95 & 0.051 & -.0000512 & .0272964 \\
\hline gamma_6_3 & -.0238624 & .0063919 & -3.73 & 0.000 & -.0363902 & -.0113345 \\
\hline gamma_7_3 & -.0647452 & .0087875 & -7.37 & 0.000 & -.0819684 & -.0475219 \\
\hline gamma_8_3 & .0220793 & .0068777 & 3.21 & 0.001 & .0085992 & .0355595 \\
\hline gamma_9_3 & .0004379 & .0035845 & 0.12 & 0.903 & -.0065876 & .0074633 \\
\hline gamma_10_3 & .0420957 & .006465 & 6.51 & 0.000 & .0294246 & .0547669 \\
\hline gamma_4_4 & .0494015 & .0098051 & 5.04 & 0.000 & .030184 & .0686191 \\
\hline gamma_5_4 & .0179415 & .006476 & 2.77 & 0.006 & .0052488 & .0306342 \\
\hline gamma_6_4 & -.0179687 & .0052153 & -3.45 & 0.001 & -.0281904 & -.0077469 \\
\hline gamma_7_4 & .0227531 & .0073704 & 3.09 & 0.002 & .0083075 & .0371988 \\
\hline gamma_8_4 & -.0001844 & .0045452 & -0.04 & 0.968 & -.0090929 & .0987241 \\
\hline gamma_9_4 & -.005031 & .0038039 & -1.32 & 0.186 & -.0124864 & .0024245 \\
\hline gamma_10_4 & .0245386 & .0044122 & 5.56 & 0.000 & .0158908 & .0331865 \\
\hline gamma_5_5 & -.0406766 & .0085835 & -4.74 & 0.000 & -.0574999 & -.0238532 \\
\hline gamma_6_5 & .0146445 & .0055494 & 2.64 & 0.008 & .0037678 & .0255211 \\
\hline gamma_7_5 & -.0279826 & .007773 & -3.60 & 0.000 & -.0432174 & -.0127479 \\
\hline gamma_8_5 & .0282935 & .0056356 & 5.02 & 0.000 & .0172478 & .0393392 \\
\hline gamma_9_5 & .0097535 & .0034696 & 2.81 & 0.005 & .0029532 & .0165538 \\
\hline gamma_10_5 & .0228567 & .0053239 & 4.29 & 0.000 & .012422 & .0332913 \\
\hline gamma_6_6 & .0084074 & .0065349 & 1.29 & 0.198 & -.0044009 & .0212157 \\
\hline gamma_7_6 & .0031676 & .0069969 & 0.45 & 0.651 & -.010546 & .0168812 \\
\hline gamma_8_6 & -.005472 & .0050714 & -1.08 & 0.281 & -.0154117 & .0044677 \\
\hline gamma_9_6 & -.0084208 & .0027506 & -3.06 & 0.002 & -.0138118 & -.0039298 \\
\hline gamma_10_6 & -.0010266 & .0046838 & -0.22 & 0.827 & -.0102067 & .0081535 \\
\hline gamma_7_7 & .0624408 & .0118944 & 5.25 & 0.000 & .0391282 & .0857535 \\
\hline gamma_8_7 & -.0427324 & .0080871 & -5.28 & 0.000 & -.0585829 & -.026882 \\
\hline gamma_9_7 & .016183 & .603959 & 4.09 & 0.000 & .0084234 & .0239426 \\
\hline gamma_10_7 & -.0301996 & .0070729 & -4.27 & 0.000 & -.0440622 & -.0163369 \\
\hline gamma_8_8 & .0088087 & .007626 & 1.16 & 0.248 & -.0061379 & .0237553 \\
\hline gamma_9_8 & -.0013754 & .0024783 & -0.55 & 0.579 & -.0062329 & .0034821 \\
\hline gamma_10_8 & .015824 & .0051324 & 3.08 & 0.002 & .0057647 & .0258834 \\
\hline gamma_9_9 & -.0082205 & .0029476 & -2.79 & 0.005 & -.0139977 & -.0024433 \\
\hline gamma_10_9 & .0042314 & .0023899 & 1.77 & 0.077 & -.0004528 & .0089155 \\
\hline gamma_10_10 & -.0118878 & .0070196 & -1.69 & 0.090 & -.025646 & .0018703 \\
\hline \multicolumn{7}{|l|}{ lambda } \\
\hline lambda_1 & - .0193392 & .0015537 & -12.45 & 0.000 & -.0223843 & -.016294 \\
\hline 1ambda_2 & -.0005552 & .000269 & -2.06 & 0.039 & -.0010824 & -.0000279 \\
\hline lambda_3 & .0106751 & .0007434 & 14.36 & 0.000 & .009218 & .0121321 \\
\hline lambda_4 & .0047641 & .0006777 & 7.03 & 0.000 & .0034359 & .0060923 \\
\hline lambda_5 & .0037201 & .0006256 & 5.95 & 0.000 & .0024939 & .0049463 \\
\hline lambda_6 & -.0035719 & .0007057 & -5.06 & 0.000 & -.004955 & -.0021888 \\
\hline lambda_7 & -.0058855 & .0006557 & -8.98 & 0.000 & -.0071707 & -.0046003 \\
\hline lambda_8 & .0022377 & .0007623 & 2.94 & 0.003 & .0007436 & .0037318 \\
\hline lambda_9 & -.0000957 & .000369 & -0.26 & 0.795 & -.0008188 & .0006275 \\
\hline lambda_10 & .0080504 & .0606714 & 11.99 & 0.000 & .0067344 & .0093664 \\
\hline
\end{tabular}




\begin{tabular}{|c|c|c|c|c|c|c|}
\hline \\
\hline eta_genderkk_1 & .0014654 & .0009866 & 1.49 & 0.137 & -.0004684 & .0033991 \\
\hline eta_genderkk_2 & -.6000879 & .0001357 & -0.65 & 0.517 & -.6003539 & .0601781 \\
\hline eta_genderkk_3 & -.6004975 & .0604802 & -1.64 & 0.360 & -.6014387 & .0604437 \\
\hline eta_genderkk_4 & -.0010003 & .0004505 & -2.22 & 0.026 & -.6018832 & -.0001174 \\
\hline eta_genderkk_5 & .0003269 & .0002965 & 1.10 & 0.270 & -.6002542 & .0009079 \\
\hline eta_genderkk_6 & .6002499 & .0004257 & 0.59 & 0.557 & -.0005844 & .0010842 \\
\hline eta_genderkk_7 & -.6000144 & .0603944 & -0.64 & 0.971 & -.0007874 & .0007585 \\
\hline eta_genderkk_8 & -.6002429 & .0004669 & -0.52 & 0.603 & -.001158 & .0606723 \\
\hline eta_genderkk_ 9 & -.000017 & .0001913 & -0.69 & 0.929 & -.0003919 & .0003578 \\
\hline eta_genderkk_10 & -.6001821 & .0004921 & -6.37 & 0.711 & -.6011466 & .0607824 \\
\hline eta_workkk_1 & .6019416 & .0013789 & 1.41 & 0.159 & -.000761 & .0046443 \\
\hline eta_workkk_2 & -.00005 & .0001762 & -0.28 & 0.777 & -.6003952 & .0602953 \\
\hline eta_workkk_3 & -.6012127 & .0006522 & -1.86 & 0.063 & -.002491 & .0000655 \\
\hline eta_workkk_4 & -.6029174 & .0006227 & -4.68 & 0.000 & -.6041379 & - .0016968 \\
\hline eta_workkk_5 & -.0064153 & .0003963 & -1.65 & 0.295 & -.001192 & .0003615 \\
\hline eta_workkk_6 & .0001937 & .0005542 & 0.35 & 0.727 & -.6008925 & .0012798 \\
\hline eta_workkk_7 & .6006915 & .0005298 & 1.31 & 0.192 & -.6003468 & .0017298 \\
\hline eta_workkk_8 & .0013604 & .0006178 & 2.20 & 0.028 & .0001496 & .0025712 \\
\hline eta_workkk_9 & -.6001693 & .0602489 & -0.68 & 0.496 & -.0006571 & .0603185 \\
\hline et a_workkk_1e & .6005774 & .0006722 & 0.86 & 0.390 & -.6007401 & .0018949 \\
\hline eta_educ_1 & .6015378 & .0001012 & 15.19 & 0.060 & .6013393 & .0017362 \\
\hline eta_educ_2 & $3.09 e-06$ & .0000132 & 0.23 & 0.816 & -.6000229 & .686029 \\
\hline eta_educ_3 & .6001284 & .0600436 & 2.95 & 0.003 & .060043 & .0602138 \\
\hline eta_educ_4 & .6060708 & .0600418 & 1.69 & 0.091 & -.6060112 & .0001528 \\
\hline eta_educ_s & -.6002252 & .00003 & -7.50 & 0.600 & -.6002841 & - .eQ01664 \\
\hline eta_educ_6 & -.6064955 & .0600423 & -11.71 & 0.060 & -.6005784 & - .e604126 \\
\hline eta_educ_7 & -.6005223 & .0600394 & -13.25 & 0.000 & -.6005995 & -.000445 \\
\hline eta_educ_ 8 & -.6064716 & .0000456 & -10.34 & 0.060 & -.000561 & -.0003822 \\
\hline eta_educ_9 & -.6060647 & .0000186 & -3.47 & 0.001 & -.6001012 & -.0000282 \\
\hline eta_educ_10 & .6060393 & .0600448 & 0.88 & 0.381 & -.6000486 & .0001271 \\
\hline eta_1okas 1 - 1 & .0102116 & .0015958 & 6.40 & 0.000 & .6070838 & .0133394 \\
\hline eta_1okasi_2 & -.6060687 & .0001146 & -0.60 & 0.549 & -.6002933 & .0601559 \\
\hline eta_lokas $1_{-} 3$ & -.6010942 & .0006883 & -1.59 & 0.112 & -.6024433 & .0002549 \\
\hline eta_1okas ${ }_{-}{ }_{4}$ & -.003335 & .0006666 & -5.60 & 0.060 & -.6046415 & -.0020286 \\
\hline eta_lokasi_5 & .6025373 & .0603474 & 7.30 & 0.060 & .0018563 & .0032182 \\
\hline eta_lokas 1 - 6 & .6001148 & .0004045 & 0.28 & 0.777 & -.000678 & .0809076 \\
\hline eta_lokasi_t & -.6041722 & .0004615 & -9.64 & 0.060 & -.6050767 & -.0032677 \\
\hline eta_lokas $1_{-} 8$ & -.6001229 & .006479 & -0.26 & 0.797 & -.6010617 & .0808158 \\
\hline eta_lokasi_9 & .6002794 & .0001656 & 1.69 & 0.092 & -.6060452 & .0606039 \\
\hline eta_lokasi_10 & -.60435 & .0007179 & -6.06 & 0.060 & -.0057571 & -.0029429 \\
\hline eta_ymarriage_1 & $9.22 e-06$ & .0000339 & 0.27 & 0.786 & -.6000573 & .0000758 \\
\hline eta_ymarriage_2 & $-5.25 e-66$ & $4.69 \mathrm{e}-66$ & -1.12 & 0.263 & -.6060145 & $3.95 \mathrm{e}-66$ \\
\hline eta_ymarriage_3 & -.6000422 & .0000165 & -2.56 & 0.010 & -.6000745 & $-9.93 \mathrm{e}-66$ \\
\hline eta_ymarriage_4 & -.6000354 & .0000157 & -2.26 & 0.024 & -.6000662 & $-4.69 e-66$ \\
\hline eta_ymarriage_5 & -.060022 & .0000103 & -2.14 & 0.033 & -.6000422 & $-1.82 \mathrm{e}-66$ \\
\hline eta_ymarriage_6 & -.6060619 & .0600146 & -4.23 & 0.060 & -.0000906 & -.0000332 \\
\hline eta_ymarriage_7 & -.6000106 & .0600137 & -0.77 & 0.438 & -.6000374 & .0000162 \\
\hline eta_ymarriage_ 8 & .6001895 & .0600165 & 11.48 & 0.060 & .0001571 & .0602218 \\
\hline eta_ymarriage_ 9 & $-5.32 e-06$ & $6.62 \mathrm{e}-66$ & -0.80 & 0.422 & -.6000183 & $7.66 \mathrm{e}-66$ \\
\hline eta_ymarriage_10 & -.6060159 & .0600169 & -0.94 & 0.347 & -.6060491 & .0800173 \\
\hline eta_usia_1 & .6002634 & .0690334 & 7.90 & 0.060 & .600198 & .0003288 \\
\hline eta_usia_2 & $-8.08 e-66$ & 4. $36 e-66$ & -1.88 & 0.060 & -.0000165 & $3.46 \mathrm{e}-07$ \\
\hline eta_usia_3 & .6060149 & .0000152 & 0.98 & 0.328 & -.6000149 & .0600447 \\
\hline eta_usia_4 & -.6060674 & .0600147 & -4.59 & 0.060 &.$- e 000962$ & - .eeee386 \\
\hline eta_usia_5 & -.6060557 & $9.33 \mathrm{e}-66$ & -5.97 & 0.060 & -.060074 & -.0600374 \\
\hline eta_usia_6 & -.6060612 & .0600134 & -4.55 & 0.060 & -.6060876 & -.0000349 \\
\hline eta_usia_7 & -.6060189 & .0600125 & -1.52 & 0.129 & -.6000433 & $5.52 \mathrm{e}-66$ \\
\hline eta_usia_8 & .6000209 & .0600147 & 1.42 & 0.155 & $-7.96 e-96$ & .000498 \\
\hline eta_usia_9 & -.6060287 & $6.16 e-66$ & -4.70 & 0.060 & -.6900406 & - .e6e0167 \\
\hline eta_usia_10 & -.6000592 & .0000159 & -3.71 & 0.000 & -.6000905 & -.600028 \\
\hline eta_hhsize_ 1 & -.6005597 & .6002 & -2.80 & 0.005 & -.6009516 & -.0001678 \\
\hline eta_hhsize_2 & .6000369 & .0000272 & 1.36 & 0.175 & -.0000164 & .0000902 \\
\hline eta_hhsize_ 3 & -.000151 & .6000984 & -1.53 & 0.125 & -.6003439 & .0600419 \\
\hline eta_hhsize_ 4 & -.6000667 & .0000932 & -0.71 & 0.475 & -.6002494 & .0001161 \\
\hline eta_hinsize_ 5 & .600255 & .0000622 & 4.10 & 0.600 & .6001332 & .0003768 \\
\hline eta_hhsize_ 6 & .6002207 & .0600857 & 2.58 & 0.010 & .6060527 & .0003887 \\
\hline eta_hinsize_7 & .6002438 &. .еeевез & 3.64 & 0.002 & .6060864 & .0604013 \\
\hline eta_hhsize_ 8 & .000162 & .0600949 & 1.71 & 0.088 & -.000024 & .0603479 \\
\hline eta_hhsize_9 & .6060759 & .0600383 & 1.98 & 0.048 & $7.87 e-07$ & .600151 \\
\hline eta_hhsize_1e & -.6002169 & .0001012 & -2.14 & 0.032 & -.6004151 & - .eอee186 \\
\hline 10 & & & & & & \\
\hline rho_genderkk & -.025686 & .0366558 & -0.70 & 0.483 & -.0975301 & .0461581 \\
\hline rhe_workkk & -.6696775 & .052859 & -1.32 & 0.187 & -.1732792 & .0339243 \\
\hline rho_educ & -.6078892 & .0031566 & -2.50 & 0.012 & -.014076 & -.0017025 \\
\hline rho_lokas i & -.6614357 & .0685021 & -9.66 & 0.000 & -.7956973 & -.5271741 \\
\hline rho_ymarriage & .000727 & .0014024 & 0.52 & 0.664 & -.6020217 & .0034756 \\
\hline rho_usia & .6018659 & .0013872 & 1.35 & 0.179 & -.000853 & .0045849 \\
\hline rho_hhsize & .0463486 & .0115912 & 4.60 & 0.000 & .0236304 & .0696669 \\
\hline
\end{tabular}

